\title{
The Mutual Intelligibility of Cameroon English and Indian English Speakers
}

\author{
Gilbert Tagne Safotso ${ }^{1}$ \\ ${ }^{1}$ Department of English, University of Maroua, Cameroon \\ Correspondence: Gilbert Tagne Safotso, P O Box 282 Dschang, Cameroon. Tel: 237-677-813172 E-mail: \\ gilbertsafotso@gmail.com \\ Received: August 19, 2015 \\ Accepted: September 11, 2015 \\ Online Published: September 14, 2015 \\ doi:10.5430/elr.v4n3p83 \\ URL: http://dx.doi.org/10.5430/elr.v4n3p83
}

\begin{abstract}
This study investigates the mutual intelligibility of Cameroon English and Indian English speakers. From the data collected in oral reading on various aspects of English and in free speech by Cameroon English speakers and Indian English speakers, the analysis is done from the New Englishes and Contrastive Analysis frame. The findings show that, contrary to the presupposed mutual intelligibility of native English speech on the one hand, and the mutual intelligibility of non-native English speech on the other, some non-native speakers of English face almost the same difficulty understanding other non-native speakers like the native speakers. Though many new Englishes share a number of common features that differentiate them from native Englishes, each variety of non-native English has some features which prevent it from being fully understood by both native speakers and speakers of other non-native varieties of English.
\end{abstract}

Keywords: CamE, IndE, Intelligibility, Non-native, New Englishes, Marker, Morpheme, Clusters, Speech

\section{Introduction}

In the literature, many studies on intelligibility have shown that there is communication breakdown between speakers of native and non-native Englishes. Apart from a few cases (Smith, 1992; Munro \& Derwing, 1995; Munro et al., 2006; Atechi, 2006), where the researchers adopted a dual-sided approach, the investigation is generally done to check to what extent the non-native speaker is intelligible or comprehensible in the ears and mind of the native speaker. According to Kachru's (1988:2) three concentric circles, the native speakers of English are found in the Inner Circle. This circle represents the traditional cultural and linguistic bases of English, and comprises the USA, the UK, Canada, Australia and New Zealand. Some of the studies which have checked the intelligibility of non-native speech in the ears of native speakers include Bansal (1969), Tiffen (1974), Benrabah (1987), Gallego (1990), Munro \& Derwing (1999), Hahn (2004), Kennedy \& Trofinovich (2008). The bias of some native speakers / listeners against accents or accented speakers make them see all non-native speech as sounding the same (Brennan $\&$ Brennan, 1981; Gass \& Varonis, 1984; Lippi-Green, 1997). This way of viewing non-native speech, coupled with the one-way investigation of intelligibility by most studies, would imply that, on the one hand, there is mutual comprehensibility among all the native varieties of English, and on the other, all the non-native varieties of English behave alike. Yet, across the world, there are many varieties of native English as well as New Englishes. In this paper, New Englishes is synonymous with World Englishes (WEs), which is used to refer to the indigenised varieties of English in their local context of use (Jenkins 2006, p.157). Wells (1982:279) distinguishes four varieties of RP (Received Pronunciation): mainstream RP, U-RP, adoptive RP and Near-RP. As he remarks, mainstream RP is the central tendency of RP. U-RP is used by the upper-class citizens such as many upper-class army officers or dowager duchesses. Adoptive RP is the variety of RP spoken by adults who did not speak RP as children. Near-RP comprises accents which are not exactly RP though not very different from it. Recent developments and tendencies in RP show that some of the changes are: the decline of the weak /I/, glottalling, 1-vocalization, intrusive /r/, yod coalescence, and lexical change (Wells, 1994:2). Fabricius (2002) argues that the widespread t-glottalling in the speech of young British ex-public school students has made it to gradually become a non-stigmatised variant in modern RP. Trudgill (2008) attributes all those changes to history and linguistic events, but argues that they are sociolinguistically nothing new or modern, and concludes that RP is not disappearing.

Graddol (2000:10) estimated 750 million speakers of English as a Foreign Language, 375 million speakers of English as a Second Language, and 375 million speakers of English as a mother tongue. In India and China alone, 
Kachru (2005) estimated that the number of English users approximates 533 million. This estimate is quite outdated in 2015. The numerous varieties of New Englishes which abound around the world include Indian English (Bansal, 1969; Gargesh, 2004), Ghanaian English (Sey, 1973), Nigerian English (Tiffen, 1974; Eka, 1985; Jowitt, 1991; Oluremi, 2013), Kenyan English (Zuengler, 1983), Cameroon English (Simo Bobda, 1994), Singapore English (Lin, 2004), Taiwan English (Chung, 2006), Cameroon Francophone English (Tagne Safotso, 2012, 2015). The non-native varieties of English are so numerous that measuring their mutual intelligibility would be an awesome task. But given the new trend of the world's development, economy and trade where the relationships are no longer only North-South, but more and more South-South among the developing (emerging) countries (e.g. Brazil, Japan, India, China and the Asian continent as a whole with Africa), the mutual intelligibility of some non-native Englishes necessitates serious investigation to see to which extent the speakers of the varieties concerned can communicate in their various transactions. Without arguing that the search for an international English pronunciation (Gimson, 1978; Pennnington, 1996; Jenkins 1998, 2000) would be a dream, the day when all English speakers around the world will be fully intelligible or comprehensible to each other is still very far.

Though India is not presently among the main economic partners of Cameroon, its growing power and population (the second largest population after China), the involvement of Indians and other Asians in many sectors in Cameroon is a strong index that in a near future this giant (India) of the Asian continent will count among the main partners of the country and Africa as a whole. In Cameroon, Indians are presently in the tractors construction sector, trade, and religious congregations. This is one of the reasons why the mutual intelligibility of Cameroon English (CamE) and Indian English (IndE) speech necessitates an in-depth investigation. Though two non-native varieties of British English, CamE belongs to the West African branch whereas IndE belongs to the South Asia one (see Gradol, 2000: 11).

\section{Method}

The data come from speech samples produced in oral reading of selected words, phrases and sentences by Indian and Cameroonian informants. This was completed by the production of free stretches of conversation on topics familiar to the subjects. The group of Indian subjects was made up of four Catholic sisters of The Daughters of the Cross Congregation, based at the Notre Dame de l'Assomption Parish in Maroua (Far North Cameroon). Sister Lina came from Goa State and spoke Konkani, Hindi, Marathi, English and French. Sister Veronica came from Maharashtra State and spoke Marathi, Hindi, English and French. Sister Puspa came from Kerala State and spoke Malayalam, Hindi, Marathi, English and French. The last sister, Jane, came from Gujarat State and spoke Gujarati, Hindi, English and French. They all had done university studies (three of them at Bombay University) before joining their congregation. So, due to the international nature of their congregation, each of the sisters spoke at least four languages including English and French. The Cameroonian group of subjects comprised eight student-teachers (students who are being trained to become English language teachers) of the Higher Teacher Training College, University of Maroua (Cameroon) of varied mother tongues. In addition to their mother tongue, each of them spoke English as a second language and Pidgin English as a lingua franca. All the eight subjects had also been doing intensive English phonology courses for two years as part of their training. The sisters were chosen as the subjects for the study, because of their training and the careful way religious men and women usually articulate their speech in daily life. As to the student-teachers, their choice was motivated by the fact that they were somehow aware of the phenomena that take place in natural rapid speech.

The first exercise for each subject consisted in reading 92 individual words, 30 sentences containing verbs with the -ed morpheme, 18 sentences containing regular plural nouns that end in $/ \mathrm{s} /$ or $/ \mathrm{z} /, 32$ sentences or phrases containing irregular plural nouns that end in /Iz/, seven sentences or phrases containing irregular plural nouns that end in /ouz/, 25 sentences containing verbs in the third person singular, 28 sentences or phrases containing the possessive case, and 45 words containing specific consonant clusters. In free speech, each of the Indian sisters had to talk of religion, life and people in Cameroon. Each topic took approximately two to three minutes. Each of the Cameroonian subjects had to talk of football, politics and development in Cameroon for the same length of time.

The second exercise consisted for each group of participants, in listening twice to the speech of the members of the other group in various exercises, and to write down what they had heard. Enough pauses were allowed after each listening to ensure that each subject had jotted down what he/she had heard.

\section{Results}

The various perceptions of CamE (Cameroon English) speakers of speech produced by IndE (Indian English) speakers and vice-versa are presented below. 


\subsection{Mutual intelligibility on single words}

At the level of single words, a selection of 30 words showed that all the IndE speakers fully understood only six of them, making a percentage of $20 \%$. Seven out of the 30 words were intelligible to 50 per cent of them $(23.33 \%)$. The remaining 17 words (56\%) were either unintelligible to all of them, or comprehensible to one subject. As to CamE speakers, six out of the 30 words were intelligible to all of them $(20 \%)$, six words to six of the subjects (20\%), and six to $50 \%$ of them. Unlike the IndE speakers, only 12 out of the 30 target words (40\%) were either unintelligible in the ears of all CamE speakers, or to less than $50 \%$ of them. Table 1 below summarises the various tendencies.

Table 1. Mutual Intelligibility of CamE and Ind E speakers on individual words: $50 \%$ and above

\begin{tabular}{cccccc}
\hline $\begin{array}{c}\text { Words } \\
\mathrm{N}=30\end{array}$ & $\begin{array}{c}\text { IndE speakers listening } \\
\text { to CamE speech, } \mathrm{N}=4\end{array}$ & $\%$ & $\begin{array}{c}\text { Words } \\
\mathrm{N}=30\end{array}$ & $\begin{array}{c}\text { CamE speakers listening to } \\
\text { IndE speech, N=8 }\end{array}$ & $\%$ \\
\hline 06 & 04 & 20 & 06 & 08 & 20 \\
07 & 02 & 23.33 & 06 & 06 & 20 \\
- & - & - & 06 & 04 & 20 \\
Mean & & 43.33 & & & 60
\end{tabular}

It can be observed that, on the same words IndE speakers are more intelligible in the ears of CamE speakers (60\%), whereas CamE words are only $43.33 \%$ comprehensible to Indians. IndE speech may also be more intelligible to CamE speakers than to the British listeners as the following table adapted from Bansal illustrates.

Table 2. Comparison of CamE speakers' and British English speakers' perception of IndE speech

\begin{tabular}{cccc}
\hline $\begin{array}{c}\text { Words by Ind E } \\
\text { speakers }\end{array}$ & $\begin{array}{c}\text { CamE speakers' responses } \\
\mathrm{N}=8\end{array}$ & $\%$ & British E speakers' responses \\
\hline suitable & suitable( 7 subjects) & 87.75 & the level \\
written & predicted $(2$ subjects) & 25 & retain \\
& victim $(2$ subjects) & 25 & \\
& between $(2$ subjects) & 25 & regions \\
divisions & divisions (6 subjects) & 75 & the child \\
Richard & Richard $(3$ subjects $)$ & 37.5 & \\
& richer $(2$ subjects $)$ & 25 & \\
\hline
\end{tabular}

Adapted from Bansal (1969: 151-156)

In the table above, all the four example words are totally unintelligible to the British listeners, whereas three of them are perceived by CamE speakers between $37.5-87.75 \%$.

\subsection{Mutual intelligibility on consonant clusters}

The two groups of subjects had no major difficulty in understanding each other's most consonant clusters. The comprehension failure was generally at the level of the whole word, structure or phrase, and not because of a deviant consonant cluster. For example, words with difficult consonant clusters like Wednesday, frankly, groundnuts [wensdr], [frænkli], [graundn $\Lambda t s]$ were mutually intelligible to all the subjects though they produced these words

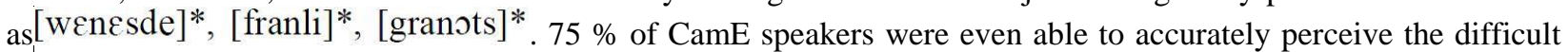
word withstand [wıðstænd] by IndE speakers though they produced it as [wiftan/wistan]*. As a matter of fact, in the literature, it is reported that on English consonant clusters many non-native Englishes share many common features: simplification, final consonant deletion, devoicing of some members of the cluster, substitution, vowel epenthesis. Gut (2005:348) reports that final consonant clusters reduction is extremely frequent in Singapore English, i.e. $85 \%$ for all types of cluster and $90 \%$ for /-t, -d/ clusters. Studying this feature in Singapore English (SingE) and Nigerian English (NigE), she later observed that the retention of final consonant clusters is common both in native English and non-native Englishes, e.g. SingE (15.52 \%), BrE (28.1\%), NigE (49.3\%), Chinese English (58.2 \%) (Gut, 2007: 350). In CamE, Masanga (1983), Mbangwana (1987), and Simo Bobda (1994) report that consonant clusters simplification, reduction or the devoicing of some members of the cluster, and vowel epenthesis are stable features. 
Tagne Safotso (2012: 2473) observes that the dropping of the last member of the cluster is very frequent in CamFE, e.g. told, went, landlord [tol], [wen], [lanlo] for RP [təuld], [w\&nt], [lændlo:d].

\subsection{Mutual intelligibility on the plural markers}

In total, there were 66 instances of nouns with the plural marker put in sentences or phrases distributed as follows: 30 examples of regular plurals (ending in -s), 28 irregular plurals ending in -es, -ies, and 09 irregular plurals ending in -oes. On regular plurals, all the eight CamE speakers perceived two of the markers by IndE speakers $(06.66 \%)$; four of the subjects perceived six of them (20\%), and nine out of the 30 markers were intelligible to six of the listeners (30\%). So, on average, 17 of the 30 regular plural markers by IndE speakers were intelligible to $50 \%$ of CamE speakers and above, giving a percentage of $56.56 \%$. On irregular plurals ending in -es/ies, all the Cameroonian listeners found nine out of 28 markers intelligible $(32.14 \%) .75 \%$ of these listeners also well perceived nine of them (32.14\%), but all the remaining ones were unintelligible to them. $64.28 \%$ of plural markers in -es/ies by IndE speakers were thus acceptably intelligible in the ears of CamE speakers listeners. However, the irregular plural markers in -oes by Indians were less intelligible to them. Only four out of the nine markers of this category produced by IndE speakers were intelligible to between four and six CamE speakers (44.44\%).

Unlike the CamE speakers subjects, the IndE speakers had enormous difficulties in understanding the regular plural markers by their Cameroonian counterparts. Only seven of the 30 markers in question were perceived by the four sisters $(23.33 \%)$. Four markers were intelligible to two of them $(13.33 \%)$. This category of plural markers by Cameroonians was thus intelligible by only $36.66 \%$ to half and above of IndE speakers listeners. On the markers in -es, -ies, the IndE speakers performed as well as their Cameroonian counterparts. 10 of the 28 markers by CamE speakers were intelligible to all the Indian subjects (35.71\%); eight markers were well perceived by two of them $(28.57 \%)$. The average mutual intelligibility, taken from $50 \%$ and above on this category of plural markers, was the same for Cameroonians $(64.28 \%)$ and Indians $(64.28 \%)$. On the markers in -oes, only three out of nine by CamE speakers were intelligible to two of the Indian listeners (33.33\%). So, $66.66 \%$ of plural markers of this category by CamE speakers were unintelligible to IndE speakers. The various findings discussed above are summarised in Table 3 which follows.

Table 3. Mutual intelligibility of CamE speakers and IndE speakers on plural markers: $50 \%$ and above

\begin{tabular}{|c|c|c|c|c|c|}
\hline $\begin{array}{l}\text { Plural } \\
\text { markers }\end{array}$ & $\begin{array}{l}\text { IndE speakers listening } \\
\text { to CamE speech, } N=4\end{array}$ & $\%$ & $\begin{array}{l}\text { Plural } \\
\text { markers }\end{array}$ & $\begin{array}{l}\text { CamE speakers listening } \\
\text { to IndE speech, } \mathrm{N}=8\end{array}$ & $\%$ \\
\hline Simple & & & Simple & & \\
\hline $\mathrm{N}=30$ & 2-4 listeners(11 markers) & 36.36 & $\mathrm{~N}=30$ & 4-8 listeners (17 markers) & 56.56 \\
\hline In & & & In & & \\
\hline -es/ies & 2-4 listeners (18 markers) & 64.28 & -es/ies & 4-8 listeners (18 markers) & 64.28 \\
\hline $\mathrm{N}=28$ & & & $\mathrm{~N}=28$ & & \\
\hline In -oes & & & In -oes & & \\
\hline $\mathrm{N}=09$ & 2 listeners (03 markers) & 33.33 & $\mathrm{~N}=09$ & 4-6 listeners (04 markers) & 44.44 \\
\hline Mean & & 47.76 & & & 58.28 \\
\hline
\end{tabular}

Table 3 shows that on plural markers, the mean intelligibility of CamE speech to IndE speakers listeners is $47.76 \%$, and that of IndE speech to CamE speakers $58.28 \%$. This is an indication that there can be serious communication breakdown between CamE and IndE speakers when dealing with plural nouns. In a conversation/discussion, for example, when one of the participants will be talking of plurality, the other(s) will be perceiving the singular form. Though many of the sample nouns had a modifier that indicated their number (plural or singular), the subjects from the two groups generally fail to understand each other. Judging a speech intelligibility between $50-100 \%$ as it has been the case throughout the study, means that, in the conversation, half of the words/utterances of the partner will not be fully understood, leading to misperception. Even by that standard, IndE speech on plural markers is hardly understood by CamE speakers listeners whereas their own speech falls below that standard in the ears of IndE speakers. Smith (1992: 81-82) put his own average intelligibility/comprehensibility/interpretability between 60-100 \%, which in normal communication is still below the norm, since $40 \%$ of the information will be lost. The next section looks at the mutual intelligibility of the two groups of subjects on the possessive case. 


\subsection{Mutual intelligibility on the possessive case}

On the possessive case, the investigations were carried out on 28 sample words made up of 16 simple names/nouns and $12 \mathrm{old} /$ classical names, e.g. Thomas' book [tpmosiz buk], George's new house [dzo:dzIz nju: haus]. The CamE speakers hardly perceived a few of the genitives by IndE speakers. Out of the 28 samples, only four were perceived by four of the Cameroonian subjects (14.28\%). As to the Indian listeners, on the possessive case, CamE speech was more intelligible. The four of them well perceived eight of the 28 samples $(28.57 \%)$, and two of them well perceived six of the cases $(21.42 \%)$. In general, on old/classical names, the two groups of subjects had enormous difficulties in understanding each other. An example like the following was reported by one of the Cameroonian subjects listening to IndE speech: price making was excellent* for 'Pius marking was excellent'. Table 4 below summarises the findings on the possessive case.

Table 4. Mutual intelligibility of CamE and IndE speakers on the possessive case: $50 \%$ and above

\begin{tabular}{lccccc}
\hline $\begin{array}{l}\text { Possessive } \\
\text { Case, N=28 }\end{array}$ & $\begin{array}{l}\text { IndE speakers listening } \\
\text { to CamE speech, N=04 }\end{array}$ & $\%$ & $\begin{array}{l}\text { Possessive } \\
\text { Case, N=28 }\end{array}$ & $\begin{array}{l}\text { CamE speakers listening } \\
\text { to IndE speech, N=8 }\end{array}$ & $\%$ \\
\hline 08 & 04 & 28.57 & 04 & 04 & 14.28 \\
06 & 02 & 21.42 & - & - & 14.28 \\
Mean & & 50 & & & 04
\end{tabular}

It can be observed that, compared to the other aspects of mutual intelligibility so far studied (individual words, consonant clusters, plural markers), the average intelligibility between CamE/IndE speakers on the possessive is the lowest. There is an almost total communication breakdown between CamE and IndE speakers on the genitive. No one can pretend to get anything in a discussion/conversation where one of the participants is $14.28 \%$ intelligible and the other one $50 \%$. Section 3.5., which follows looks at the mutual intelligibility on the $3^{\text {rd }}$ person singular marker.

\subsection{Mutual intelligibility on the 3rd person singular marker}

The analysis was done on 30 samples of verbs in the $3^{\text {rd }}$ person singular distributed as follows: six verbs ending in /s/, e.g. she likes [ $\mathrm{j} \mathrm{i}: \mathrm{laIks}]$, i.e. verbs ending in the infinitive in a voiceless consonant; 19 verbs ending in /z/, i.e. verbs ending in the infinitive in a voiced consonant or a vowel; and five verbs ending in /Iz/, i.e. those ending in the infinitive in $/ \mathrm{s}, \mathrm{z}, \int, 3, \mathrm{t} \int \mathrm{d} 3 /$. Six to eight CamE speakers were able to perceive 28 of the markers of the $3^{\text {rd }}$ person singular by the IndE speakers $(93.33 \%)$. As to the Indian listeners, all the four subjects perceived only eight markers by the CamE speakers (26.66\%). Six other markers were intelligible to only two of them (20\%). Thus, on average, on the $3^{\text {rd }}$ person singular markers, CamE speech is intelligible to IndE speakers only by $46.66 \%$ while that of IndE is $93.33 \%$ intelligible to Cameroonian listeners. The big gap between the two averages here is hard to explain as the devoicing of $/ \mathrm{z} /$ or its deletion in some clusters are common features of CamE, IndE and many other non-native Englishes (Simo Bobda, 1994; Gut, 2007; Khan, 2012). As student-teachers of English, the CamE speakers may have made use of their knowledge of English grammar to guess most of the markers by IndE speakers, since the subject of each of the verb was clear enough. The section which follows examines the intelligibility on the past tense/ past participle -ed morpheme, which is another area which poses enormous difficulties to many non-native speakers of English.

\subsection{Mutual intelligibility on the -ed morpheme}

The test here was based on 30 sentences containing verbs/past participles that end in -ed morpheme. The sample contained five items ending in -ted //tId/, three ending in -ded /dId/, seven ending in an unvoiced consonant+ ed /t/, and 22 ending in vowel or a voiced consonant+ ed /d/. $80 \%$ of Cameroonian listeners correctly perceived four out of five of the five words ending in -ted morpheme by the IndE speakers. Two of the three items ending in -ded morpheme were intelligible to all of them $(66.66 \%)$. As to the verbs/past participles ending in a voiceless consonant, the -ed of all the seven samples were correctly perceived by four to six of the Cameroonian listeners (100\%). Six CamE speakers also well perceived 13 -ed of the 22 samples of verbs/past participles that end in a vowel or a voiced consonant $(59.09 \%)$. On average, on -ed morpheme, IndE speech can thus be said to be $70.02 \%$ intelligible to CamE speakers listeners. To IndE speakers, CamE speech did not enjoy the same intelligibility rate. The four Indian listeners perceived only two of the -ted morphemes by CamE speakers (40\%). Only two of the three -ded morpheme by their Cameroonian counterparts were intelligible to two of them $(66.66 \%)$. Of the seven verbs/past participles that end in a voiceless consonant, five were well perceived by two Indian subjects (71.42 \%). Of the 22 verbs/past participles ending in a vowel or a voiced consonant by CamE speakers, only eight of their -ed morphemes were 
intelligible to two to four Indian listeners $(36.36 \%)$. So, on the -ed morpheme, the average intelligibility of CamE speech to IndE speakers is $45.59 \%$. The various findings are tabulated below.

Table 5. Mutual intelligibility of CamE and IndE speakers on the -ed morpheme: $50 \%$ and above

\begin{tabular}{|c|c|c|c|c|c|}
\hline $\begin{array}{l}\text {-ed } \\
\text { morpheme } \\
N=37\end{array}$ & $\begin{array}{l}\text { IndE speakers listening } \\
\text { to CamE speech, } \mathrm{N}=04\end{array}$ & $\%$ & $\begin{array}{l}\text {-ed } \\
\text { morpheme } \\
\mathrm{N}=37\end{array}$ & $\begin{array}{l}\text { CamE speakers listening } \\
\text { To IndE speech, } \mathrm{N}=08\end{array}$ & $\%$ \\
\hline -ted /tId/ & & & -ted / tId / & & \\
\hline $\begin{array}{l}\mathrm{N}=05 \\
-\mathrm{ded} / \mathrm{dId} /\end{array}$ & 04 (two morphemes) & 40 & $\begin{array}{l}\mathrm{N}=05 \\
-\mathrm{ded} / \mathrm{dId} /\end{array}$ & 04-08(four morphemes) & 80 \\
\hline $\mathrm{N}=03$ & 02 (two morphemes) & 66.66 & $\mathrm{~N}=03$ & 08 (two morphemes) & 66.66 \\
\hline$-\mathrm{ed} / \mathrm{t} /$ & & & $-\mathrm{ed} / \mathrm{t} /$ & 04-06 (seven & \\
\hline $\mathrm{N}=07$ & 02 (five morphemes) & 74.42 & $\mathrm{~N}=07$ & Morphemes) & 100 \\
\hline$-e d / d /$ & & & $-\mathrm{ed} / \mathrm{d} /$ & & \\
\hline $\mathrm{N}=22$ & $\begin{array}{l}\text { 02-04(eight } \\
\text { morphemes) }\end{array}$ & 36.36 & $\mathrm{~N}=22$ & 06 (13 morphemes) & \\
\hline Mean & & 45.59 & & & 70.02 \\
\hline
\end{tabular}

As with the mutual intelligibility on the $3^{\text {rd }}$ person singular marker studied in 3.4, it can be noticed that IndE speech remained relatively intelligible to CamE speakers here, with an average intelligibility of $70.02 \%$. CamE speech remained unintelligible to IndE speakers with a percentage of $45.59 \%$. In CamE and IndE the -ted and -ded morphemes are respectively pronounced $/ \mathrm{t} \varepsilon \mathrm{t} / /$ and $/ \mathrm{d} \varepsilon \mathrm{t} / . / \mathrm{d} /$ is devoiced or dropped in word final position, and /t/ is most of the time dropped at that position in the two varieties of English. The gap in the intelligibility rate is thus difficult to explain. As already mentioned, the Cameroonian listeners, as student-teachers of English, may have made use of their knowledge of the English grammar to better interpret the sentences by IndE speakers. The last section, which follows, deals with the mutual intelligibility of the two groups of subject in free speech.

\subsection{Mutual intelligibility in free speech}

To better assess the mutual intelligibility of the two groups of subjects from a different angle, each group also had to listen to the other's speech in free utterances, since in real life situation people have to interact with language. As mentioned in Section 2, the Indian sisters had to talk freely on religion, life and people in Cameroon. The Cameroonian subjects had to express themselves on football, politics and development. As illustrated below, it was in free speech that the greatest mutual unintelligibility came out, e.g.

IndE speaker's utterance (a): According to me, here in Maroua, people of different religions, muslim, protestant, they stay together, and because of religion they don't have any differences.

CamE speakers' perception:

1. According to me...right, slim, protestant, .together, these stay together...baby, princess. *

2. According to me...people of different religions, catholic, muslim, protestant, they stay together, because of religion they don't have the need to protest*.

3. According to me here in my...the birth of religion catholic, protestant, muslim, they stay together, and because of religion the princess*.

IndE speaker's utterance (b): Especially, I can see that in their life they give much importance in clothing than eating and meditating.

CamE speakers' perception:

1. Specially I can see that there are much important, it could be eating and medical*.

2. Specially I can ... in that life is important in medical and clothing*.

3. Initially in their lives there need more than physical eating and drinking*. 
CamE speaker's utterance (a):To me, I'm not very comfortable, but it's not required to everybody to work in politics, but to me the main problem that I see in politics is that politicians themselves are not very, they are not upright.

IndE speakers' perception:

1. ...I'm not politics, but... *

2. I am not very political... bishops themselves are not very. *

CamE speaker's utterance (b): Football in Cameroon I can say it's a very good and sportive act that makes all Cameroonians behave.

IndE speakers' perception:

1....People of Cameroon very good sportive, but they are very...*

2.Football in Cameroon I can say is a very good and sportive act, but it's all the Cameroonians together.*

Though the mutual intelligibility rate cannot be assessed here in percentage as in the other areas studied so far, the examples above show that CamE and IndE speakers can hardly understand each other in real conversations/discussions. The heavy data collected which cannot all be listed in an article contain many more examples.

\section{Discussion and conclusion}

This study shows that CamE and IndE speakers in various areas of English are hardly mutually intelligible. Except on consonant clusters, in none of the areas studied, the mutual intelligibility rate reaches $50 \%$. For example, on the $3^{\text {rd }}$ person singular marker, IndE speech is $93.33 \%$ intelligible to CamE speakers listeners, while that of CamE speakers is only $46.66 \%$ intelligible to them. On the possessive case, CamE speech is $50 \%$ intelligible to the Indian listeners, and that of IndE speakers is only $14.23 \%$ to them. The greatest incomprehensibility is in free speech. This difficulty in understanding some CamE speech somehow confirms an anecdote I got from the Indian sisters on this variety of English some time after the test, and from some American students of the SIT (School for International Training) Program some years before. The Indian sisters told me that despite their poor mastery of French, in Cameroon, they preferred to listen to it than to English. While watching the CRTV (Cameroon Radio Television) 7:30 News some year ago, I drew the attention of my American students guests that it was news time. But surprisingly, they asked me whether the news was being broadcast in French or in English. A bit amused, I answered: "In English". And one of them reacted: "Really ?". This was because they could hardly get anything from what the speaker was saying.

A quick look at the phonology of the two varieties of English in contrast here, however, shows that, like other non-native Englishes, they share a number of common features. But they also have many different features that predispose them to mutual unintelligibility. For example, the simplification of consonant clusters, the devoicing of the final consonant, or substitution of some consonants or vowels, are characteristic of the two New Englishes. In monophthongs, apart from /æ/ which is realised as $/ \varepsilon /$ in IndE but /a/ in CamE, e.g. trap [trep] (Gargesh, 2004: 994), the two varieties of English share almost the same vowels. The following features reported in IndE (Gargesh, 2004: 998-999) are not observed in CamE. /s, z/ do not occur in IndE while they are well attested in CamE. /s/ is replaced by $/ \int /$ in IndE, e.g. same $\left[\int \mathrm{em}\right]^{*}$ for $[\mathrm{serm}] ; / z /$ is replaced by $/ \mathrm{d} 3 /$, e.g. freeze [frid:dz], and $/ 3 /$ by $/ \mathrm{d} 3, \mathrm{j}, \mathrm{z}, /$ e.g. pleasure [pledzər/ plajər/ plezər] . But the Indian subjects of this study successfully articulated /z/ in refuse and trousers [rrfju:z], [trozos]* . In South India where the subjects come from, $/ \mathrm{h} /$ is dropped as in CamFE (Cameroon Francophone English), but is replaced by a /j/ insertion, e.g. hill, had [jil, jad]* for [hil, hæd] (Gargesh, 2004:998). That feature was exhibited by all the four Indian sisters on words like here, houses. Another feature of IndE which is notnoticeable in CamE is the substitution of $/ \mathrm{v} /$ for the semi vowel /w/, e.g. power [pavər]*. This feature of IndE rendered the following words unintelligible to CamE speakers listeners: wars, whips, watches. Though IndE and CamE share some word stress features with respect to RP, they still have many differences that prevent their mutual intelligibility. IndE and CamE stress structure words such as articles, prepositions, auxiliary verbs, etc. The Indian subjects of this study had the tendency to stress most of the disyllabic and polysyllabic words on the ultimate syllable, e.g. accor'ding, peo'ple, diffe'rent, reli'gion, catho'lic, a'ny, al'so, toge'ther, protes'tant'. (Gargesh, 2004:1001) explains this feature in the following way: in disyllabic words, the stress is on the penultimate syllable if it is not followed by an extra heavy syllable, otherwise it falls on the ultimate syllable. In tri-syllabic words, the stress falls on the penultimate syllable if it is heavy, otherwise on the antepenultimate. In CamE, word stress has the tendency to fall towards the end of the words (Mbangwana 1987, Simo Bobda 1994), e.g. an'nex, 
ca'lendar, holi'day, in'teresting*. In short, there are many particular features of IndE and CamE which prevent the speakers of the two varieties of New Englishes to be fully mutually intelligible.

\section{References}

Atechi, S.N. (2006). The Intelligibility of Native and Non-Native English Speech. Gottengen: Cuvillier Verlag.

Bansal, R. K. (1969). The Intelligibility of Indian English. Monograph n4. .Hyderabad: Central Institute of English

Bansal, R.K. (1978). The Phonology of Indian English. In R. Mohan (ed.), Indian Writings in English. Madras: Orient Longman, pp. 101-113.

Benrabah, M. (1987). The Intelligibility of Algerian Speakers of English. International Review of Applied Linguistics, 35 (3), 157-165.

Chung, K. (2006). The Phonetics and Phonology of Taiwan English. National Science Council.

Brennan, E \& Brennan, J. (1981). Measurements of accent and attitude toward Mexico-American speech. Journal of Psycholinguistic Research, 10, 487-501. http://dx.doi.org/10.1007/BF01076735

Eka, D.A. (1985). A Phonological Study of Standard Nigerian English. Unpublished PhD Thesis. ABU, Zaria: University of Zaria.

Fabricius, A. (2002). Ongoing Change in RP: Evidence for the Disappearing Stigma of t-glottalling. English World-Wide, 23 (1), 115-136. http://dx.doi.org/10.1075/eww.23.1.06fab

Gallego, J.C. (1990). The Intelligibility of True Non-native English-Speaking Teaching Assistants: An Analysis of Student-Reported Communication Breakdown. Issues in Applied Linguistics, 1(2), 219-237.

Gargesh, R. (2004). Indian English: Phonology. In B. Kortman, Sneider, E.W.,Meshire, R, and Upton, eds. A Handbook of Varieties of English. Vol.1: Phonology. Berlin: Mouton De Gruyter, pp. 992-1002.

Gass, S. \& Varonis. (1984). The effect of familiarity on the comprehensibility of nonnative speech. Language Learning, 34, 65-89. http://dx.doi.org/10.1111/j.1467-1770.1984.tb00996.x

Gimson, A.C. (1978). Toward an International Pronunciation of English. In Honour of A.S.Hornby. Oxford: Oxford University Press.

Graddol, D. (2000). The Future of English? A Guide to forecasting the popularity of the English language in the $21^{\text {st }}$ century. London: The British Council.

Gut, U. (2005). The realisation of final plosives in Singapore English: phonological Rules and ethnic differences. In Deterigng, D. et al. eds. (2005), English in Singapore. Phonetic Research on a Corpus. Singapore: McGraw-Hill, pp.14-25.

Gut, U. (2007). First language influence and final consonant clusters in the new Englishes of Singapore and Nigeria. World Englishes, .6 (3), 346-359. http://dx.doi.org/10.1111/j.1467-971X.2007.00513.x

Hahn, L. (2004). Primary Stress and Intelligibility: Research to Motivate the Teaching of Suprasegmentals. TESOL Quarterly, 38, 201-223. http://dx.doi.org/10.2307/3588378

Jenkins, J. (1998). Which pronunciation norms and model for English as an International Language? Language Teaching, 23 (4), 205-213. http://dx.doi.org/10.1093/elt/52.2.119

Jenkins, J. (2000). The Phonology of English as an International Language. Oxford: Oxford University Press.

Jenkins, J. (2006). Current Perspectives on Teaching World Englishes and English as a Lingua Franca. TESOL Quarterly, 40 (1), 157-181. http://dx.doi.org/10.2307/40264515

Jowitt, D. (1991). Nigerian English Usage: An Introduction. Ikeja: Longman Nigeria Plc.

Kachru, B.B. (1988). Teaching World Englishes, ERIC / CLL, 12 (1), 2-5.

Kachru, B.B. (2005). Asian Englishes: Beyond the canon. Hong Kong, SAR: University of Hong Kong Press.

Khan, F. (2012). Final consonant cluster simplification in a variety of Indian English. In Cheshire, J. (ed.), English around the World: Sociolinguistic Perspectives. Cambridge: Cambridge University Press, pp. 228-298. http://dx.doi.org/10.1017/CBO9780511611889.020

Kennedy, S. \& Trofinovich, P. (2008). Intelligibility, Comprehensibility, and Accentedness of L2 Speech: The Role of Listener Experience and Semantic Context. The Canadian Modern Language Review, 64 (3), 459-489. http://dx.doi.org/10.3138/cmlr.64.3.459 
Lin, L. (2004). Singapore English. Amsterdam: Benjamins.

Lippi-Green, R. (1997). English with an accent: Language, ideology, and discrimination in the United States. London: Routledge.

Masanga, D.W. (1983). The Spoken English of Educated Moghamo People: A Phonological Study. Unpublished Thesis for the $3^{\text {rd }}$ Cycle Doctorate. Yaounde: University of Yaounde.

Mbangwana, P.N. (1987). Some Characteristics of Sounds Patterns of Cameroon Standard English. Multilingual, 6 (4), 411-424. http://dx.doi.org/10.1515/mult.1987.6.4.411

Munro, M..J. \& Derwing, T..M. (1995). Processing time, accent, and comprehensibility in the perception of native and foreign-accented speech. Language and Speech, 38, 289-306.

Munro, M.. J. \& Derwing, T..M. (1999). Foreign accent, comprehensibility, and Intelligibility in the speech of second language learners. Language Learning, 49, 285-310. http://dx.doi.org/10.1111/0023-8333.49.s1.8

Munro, M..J, Derwing, T..M. \& Morton, S.L. (2006). The Mutual Intelligibility of L2 Speech. Studies in Second Language Acquisition, 28 (1), 111-131. http://dx.doi.org/10.1017/s0272263106060049

Oluremi, A. O. C. (2013). Lexico-Grammatical Features of Nigerian English. International Journal of English Education, 1 (1), 261-71. DOI: 10.5696/ijele.vlil.3316.

Pennington, M.C. (1996). Phonology in English Language Teaching. London: Longman.

Sey, K.A. (1973). Ghanaian English. London: Longman.

Simo Bobda, A. (1994). Aspects of Cameroon English Phonology. Bern: Peter Lang.

Smith, L.E. (1992). Spread of English and Issues of Intelligibility. In Kachru, B.B. ed. (1992), The Other Tongue, English across cultures. Urbana and Chicago: University of Illinois Press, pp.75-90.

Safotso, G. T. (2012). Aspects of Cameroon Francophone English Phonology. Theory and Practice in Language Studies, 2. (12), 2471-2477. http://dx.doi.org/10.4304/tpls.2.12.2471-2477

Safotso, G. T. (2015). A Study of the Phonological Features of Cameroon Francophone English. Saarbrücken: Scholars' Press.

Tiffen, W.B. (1974). The intelligibility of Nigerian English. Unpublished PhD Thesis. London: University of London.

Trudgill, P. (2008). The Historical Sociolinguistics of Elite Accent Change: On Why RP is Not Disappearing. Studia Anglica Posnaniensia, 44, 1-12.

Wells, J.C. (1982). Accents of English, 3 vols. Cambridge: Cambridge University Press. http://dx.doi.org/10.1017/cbo9780511611759

Wells, J.C. (1994). The Cockneyfication of RP? In Melchers, G. and Johannesson, N.L. (eds) Nonstandard varieties of language. Stockholm: Almqvist \& Wiksell International, pp.1-6.

Zuengler, J.E. (1983). Kenyan English. In Kachru, B.B. (ed.), The other Tongue. Oxford: Pergamon, pp. 112-124. 